221

Received:October 22, 2016

Accepted: November 25, 2016
Macedonian Journal of Animal Science, Vol. 6, No. 2, pp. 101-105 (2016)

In print: ISSN $1857-6907$

On line: ISSN $1857-7709$

UDC: $334.722: 332.14 / .15(497.774 / .775)$

Original scientific paper

\title{
ENTREPRENEURSHIP AS TOOL FOR RURAL DEVELOPMENT IN THE PELAGONIA PLANNING REGION IN THE REPUBLIC OF MACEDONIA
}

\author{
Tošo Kostadinov \\ Ss. Cyril and Methodius" University in Skopje, Institute of Animal Science, \\ Blvd. Ilinden, 92A; P.O. box. 207, 1000 Skopje, Republic of Macedonia, \\ tosokostadinov@gmail.com
}

\begin{abstract}
The aim of this paper is to incorporate new findings in the body of knowledge regarding entrepreneurship in rural areas of the Southeast Region in the Republic of Macedonia. In that view interviewing was conducted with 15 owners of SMEs in rural areas who were presented four sets of statements that are important for understanding of the situation with entrepreneurship in rural areas of the Pelagonia Planning Region in the Republic of Macedonia, valued at a five-degree scale from irrelevant to that of priority. One of the conclusions, by which the state of entrepreneurship and SMEs in rural areas of the Pelagonia Planning Region in the Republic of Macedonia is assessed - based on empirical research and compared with the results of an identical research on rural entrepreneurship on the territory of the Republic of Macedonia - is that the rural entrepreneur from that region of the country has more positive attitudes regarding entrepreneurship than the attitudes in rural areas of Macedonia. Most important development priorities of the region in the coming period should be: 1) Improving the connection between the municipalities in the region, as well as between the region and other countries, by planning and constructing a modern infrastructure. 2) Improving the environment by reducing pollution, removing the consequences of pollution and increasing energy efficiency. 3) Raised life quality and improved social cohesion in the region, through continuous investment in human resources. 4) Local economic development in the Pelagonia Region.
\end{abstract}

Key words: Pelagonia planning region in the Republic of Macedonia; rural entrepreneurship; rural entrepreneurs; SMEs; rural area

\section{ПРЕТПРИЕМНИШТВОТО КАКО АЛАТКА ЗА РУРАЛЕН РАЗВОЈ ВО ПЕЛАГОНИСКИОТ ПЛАНСКИ РЕГИОН ВО РЕПУБЛИКА МАКЕДОНИЈА}

Целта на овој труд е да се вклучат нови наоди во корпусот на знаење за претприемништвото во руралните области на Пелагонискиот плански регион во Република Македонија. Во тој поглед спроведено е интервјуирање со 15 сопственици на мали и средни претпријатија во руралните области на кои им беа презентирани четири групи на искази што се важни за разбирање на ситуацијата со претприемништвото во руралните средини во Пелагонискиот плански регион во Република Македонија, со вредност од пет-степена скала од несоодветни до онаа на Приоритет. Еден од заклучоците, со што - врз основа на емпириски истражувања и во споредба со резултатите од идентично истражување на руралното претприемништвото на територијата на Република Македонија - се проценува состојбата на претприемништвото на малите и средни претпријатија во руралните области на Пелагонискиот плански регион во Република Македонија е дека руралните претприемач од тој регион на земјата има повеќе позитивни ставови во однос на претприемништвото од соодветните ставови во руралните области на Македонија. Најважните приоритети за развој на регионот во наредниот период треба да бидат: 1) Подобрување на врската помеѓу општините во регионот, како и помеѓу регионот и други земји, преку планирање и изградба на модерна инфраструктура. 2) Подобрување на животната средина преку намалување на загадувањето, отстранување на последиците од загадувањето и зголемување на енергетската ефикасност. 3) Подигање на квалитетот на животот и подобрување на социјалната кохезија во регионот, преку континуирано вложување во човечките ресурси. 4) Локален економски развој во Пелагонискиот регион.

Клучни зборови: Пелагониски плански регион; рурално претприемништво; рурален претприемач; МСП; рурални подрачја 


\section{INTRODUCTION}

The Pelagonia Planning Region includes the basins of Pelagonia and Prespa valley and covers an area of $4.717 \mathrm{sqkm}$ or $19 \%$ of the total area of the Republic of Macedonia, and is thereby the largest planning region in the country. This region has 9 municipalities and 343 settlements, 338 of which are rural.

Population density in the region is 50 inhabitants/sqkm, and it is significantly below the national average. Most of the population is concentrated in the two largest municipalities Bitola and Prilep, while two thirds of the municipalities are located in the areas of low population density.

The region borders Albania and Greece to the south. Communication with the neighbouring countries happens through border crossings: Stenje near Resen with Albania and Medjitlija near Bitola with Greece.

The Pelagonia Planning Region has favourable climate for development of agriculture, and especially for growing industrial crops such as cereals (wheat, barley and corn, sugar beat, sunflower), tobacco, vegetables (paprika, onion) and fruit (apple).The relief of the region enables irrigation of most of the agricultural land in the catchment area of Prilep. The cold mineral springs near the village of Medjitlija, Bitola are are significant mineral resources that are being used.

Most significant water resources in the Pelagonia Planing Region are the river Crna, the energy producing capacities of which are not fully utilized (the planned hydro-electric power stations Chebren and Galishte will be the largest hydroelectric power plants in the country), and Prespa Lake, which offers potentials for development of summer tourism in the region. Water bodies of special significance for irrigation of arable land in the region are the reservoirs Strezhevo and Prespa Lake.

This region is rich with cultural and historical heritage. Especially significant are the archaeological site Heraklea, the city architecture of $\mathrm{Bi}$ tola, the traditional architecture of Krushevo, as well as the numerous churches, mosques and monasteries, urban and rural monument sites etc. The city of Bitola is known as the literacy centre of the Albanians.

The natural heritage in the region is especially abundant: the National Park Pelister, numerous natural monuments, including Prespa Lake, the citadel Markovi Kuli, several nature reserves, etc. The diversity and abundance of cultural, historical and natural riches create a high potential for the development of various types of tourism (lake, mountain, monastery, village tourism, etc.) and the utilization of those potentials can contribute to the development of the region.

The Pelagonia Planning Region has a per capita GDP of $3.577 €$, which is approx. $10 \%$ more than national average for the Republic of Macedonia. Hence, the region is ranked second of the eight planning regions in the country and contributes $12.5 \%$ to the total Macedonian GDP. The most significant economics sectors in the region are energy and food industry, as well as textile, tobacco and construction.

\section{MATERIALS AND METHODS}

The aim of this research is based upon relevant literature, documents and particularly an analysis of relevant sample of interviews (owners of $15 \mathrm{SMEs}$ ) to observe the conditions of the rural entrepreneurship in rural parts of the Pelagonia Planning Region. The comparison of the obtained results with those relevant to the rural parts on the whole territory of the Republic of Macedonia (interviewed suitable sample of owners of 101 SMEs) puts mole light on the entrepreneurship in the researched region.

Several commonly used methods of economic analysis were applied in the composition of this paper, primarily the method of generalization and specialization, the method of induction and deduction, statistical method and the comparative method.

\section{RESULTS AND DISCUSSION}

Survey respondents were offered four sets of statements that are of relevance to the efforts to perceive the situation of rural entrepreneurship in the Pelagonia Planning Region in the Republic of Macedonia, valued at a five-degree scale from 1 unimportant to 5 - priority (Table 1, 2, 3 and 4).

The results are compared to those obtained from rural areas on the territory of the whole Republic of Macedonia.

Compared with the obtained results from SMEs in rural areas on the whole territory of the Republic of Macedonia, the level of remarks from SMEs in the rural areas of Pelagonia region related to the obstacles that limit the growth of enterprises are slightly less expressed. 
Table 1

Degree of agreement with the statements in terms of constraints on the development of enterprises using the arithmetic means

\begin{tabular}{lcc}
\hline \hline & \multicolumn{2}{c}{ Mean value (rural areas) } \\
\hline High rate of VAT & 3.60 & 3.33 \\
Problems with collection of claims & Republic of Macedonia & Pelagonia planning region \\
High rates of tax and employee contributions & 3.65 & 3.54 \\
Administrative difficulties and complex of procedures & 4.18 & 3.90 \\
Instability and ambiguity of the legislation & 3.99 & 3.71 \\
High interest rates on loans & 4.02 & 3.80 \\
Cost of energy & 4.28 & 4.01 \\
Cost of material, raw materials & 3.92 & 3.85 \\
Availability of funding sources & 3.80 & 3.66 \\
Loss of market in the former Yugoslavia & 3.99 & 3.33 \\
Unfair competition & 3.03 & 2.80 \\
Domestic competition & 3.70 & 3.61 \\
Obsolete technology & 3.86 & 3.60 \\
Quality of products & 3.40 & 3.30 \\
Products prices & 3.30 & 3.24 \\
Labour costs & 3.32 & 3.19 \\
Non-innovative products & 3.32 & 3.20 \\
Lack of funds for research and development & 3.12 & 3.07 \\
\hline \hline
\end{tabular}

Source: own calculations

Table 2

Degree of agreement with the statements related to improvement of the competitiveness on the market using arithmetic means.

\begin{tabular}{|c|c|c|}
\hline & \multicolumn{2}{|c|}{ Mean value (rural areas) } \\
\hline & Republic of Macedonia & Pelagonia planning region \\
\hline Improving the quality of products and services & 4.17 & 4.33 \\
\hline Improving the promotion of products & 4.20 & 4.29 \\
\hline Obtaining quality certifications & 4.03 & 4.18 \\
\hline Professional consulting assistance & 3.46 & 3.59 \\
\hline Improvement and education in the field of entrepreneurship & 3.83 & 3.91 \\
\hline Improvement and education in the field of IT & 3.88 & 4.04 \\
\hline Improvement and education in the field of management & 3.83 & 3.89 \\
\hline Improvement and education in finance & 3.65 & 3.77 \\
\hline Improvement and education in the field of sales & 3.89 & 3.99 \\
\hline Improvement and education in marketing & 3.91 & 4.04 \\
\hline Improvement and education in foreign languages & 3.38 & 3.30 \\
\hline $\begin{array}{l}\text { Association with companies in the sector for joint appearance on } \\
\text { the market }\end{array}$ & 3.37 & 3.41 \\
\hline Assistance from development programs through grants & 4.31 & 4.51 \\
\hline Assistance from development programs through favorable loans & 4.30 & 4.39 \\
\hline Assistance from development programs through guarantee funds & 3.80 & 3.89 \\
\hline
\end{tabular}

Source: own calculations 
Table 3

Degree of agreement with claims with regard to plans for the business future (arithmetic means)

\begin{tabular}{lcc}
\hline \hline & \multicolumn{2}{c}{ Mean value (rural areas) } \\
& Republic of Macedonia & Pelagonia planning region \\
\hline Introducing new products or services & 4.08 & 4.29 \\
Sales on a new market & 3.37 & 3.52 \\
Exploring new markets & 3.32 & 3.37 \\
Search for new distribution channels & 3.61 & 3.75 \\
Expanding advertising and promotion & 3.87 & 3.99 \\
Investing in new equipment and machinery & 3.69 & 3.78 \\
Replacement of current equipment and machinery & 3.73 & 3.88 \\
Expansion of current facilities & 3.68 & 3.79 \\
Redesign/new arrangement of the current facilities & 3.42 & 3.49 \\
Search for additional financial capital & 3.92 & 4.05 \\
Computerization of current operations & 3.29 & 3.35 \\
Upgrading of computer systems & 3.38 & 3.45 \\
Redesign of work activities & 3.29 & 3.39 \\
Expanding the scope of work activities & 3.77 & 3.86 \\
Search for professional or technical advice & 3.45 & 3.59 \\
Additional engagement of staff specialists & 3.37 & 3.47 \\
Investing in staff training (elsewhere / not in the company) & 2.63 & 2.88 \\
\hline \hline
\end{tabular}

Source: own calculations

Table 4

Degree of agreement with the statements in terms of attitudes to entrepreneurship, using the arithmetic means

\begin{tabular}{|c|c|c|}
\hline & \multicolumn{2}{|c|}{ Mean value (rural areas) } \\
\hline & Republic of Macedonia & Pelagonia planning region \\
\hline business is the most important activity in my life & 4.13 & 4.30 \\
\hline ould do everything that is needed for my business to succeed & 4.18 & 4.29 \\
\hline an to sell my business at the end & 2.15 & 2.01 \\
\hline $\begin{array}{l}\text { ould like to significantly contribute to the community by developing } \\
\text { a successful business }\end{array}$ & 4.29 & 4.42 \\
\hline $\begin{array}{l}\text { ould prefer to have my own business than to earn higher wages } \\
\text { working for someone else }\end{array}$ & 4.78 & 4.89 \\
\hline $\begin{array}{l}\text { run your own business is more important than have more time for } \\
\text { the family }\end{array}$ & 3.80 & 3.95 \\
\hline $\begin{array}{l}\text { ould prefer to have my own business than to have another promising } \\
\text { career }\end{array}$ & 4.08 & 4.19 \\
\hline $\begin{array}{l}\text { the entrepreneur it is important to understand and accept the risk in } \\
\text { order to start and run a successful business }\end{array}$ & 4.26 & 4.38 \\
\hline $\begin{array}{l}\text { n ready to get into conflict with my family for the sake of running } \\
\text { my business }\end{array}$ & 3.70 & 3.88 \\
\hline ould put my house mortgaged to acquire capital for my business & 3.52 & 3.59 \\
\hline $\begin{array}{l}\text { ould be ready to have less security for my family in order to run my } \\
\text { business }\end{array}$ & 3.67 & 3.76 \\
\hline $\mathrm{n}$ my business to continue the family tradition & 3.34 & 3.49 \\
\hline $\mathrm{n}$ my business to contribute to the welfare of my relatives & 3.52 & 3.59 \\
\hline $\mathrm{n}$ my business to live in a place that my family likes & 3.47 & 3.60 \\
\hline $\mathrm{n}$ my business to improve the status and prestige of my family & 4.02 & 4.23 \\
\hline $\begin{array}{l}\text { n my business to have more flexibility in my personal and family } \\
\text { life }\end{array}$ & 4.08 & 4.22 \\
\hline
\end{tabular}

Source: own calculations 
Compared to the results of the survey on SMEs in rural areas throughout the Republic of Macedonia, SMEs from the rural areas in the Pelagonia Region, still indicate to be more competitive on the market.

The results of the comparative study demonstrated a certain degree of greater focus on future business plans for their own SMEs in the rural areas of the Pelagonija, compared to SMEs in rural areas of the country.

Generally speaking, the responses to this set of statements indicate positive attitudes towards entrepreneurship. However, the answers from SMEs in rural areas of the Pelagonija region give us the right to say that attitudes towards entrepreneurship among SMEs in the region are more positive than the views expressed by SMEs in rural areas throughout the territory of the Republic of Macedonia.

\section{CONCLUSION}

In comparison with the results obtained from SMEs in rural areas on the whole territory of the Republic of Macedonia, the level of remarks from SMEs in the rural areas of Pelagonia region related to the obstacles that limit the growth of enterprises is positioned slightly lower.

Compared to the results obtained from the survey data on SMEs in rural areas throughout the Republic of Macedonia, responses from SMEs of the rural areas in the Pelagonia Region indicate slightly higher competitive level on the market.

The results of the comparative research show a degree of greater focus on plans for the businesses of SMEs in the rural areas of the Pelagonija region for the future, compared to SMEs in rural areas of the country.

The answers from SMEs in rural areas of the Pelagonija region indicate that attitudes towards entrepreneurship among SMEs in that region are more positive than the views expressed by respon- dents from SMEs in rural areas throughout the Republic of Macedonia.

Major development priorities of the region for the coming period are:

1) Improving the connection between the municipalities in the region, as well as between the region and other countries, by planning and constructing a modern infrastructure.

2) Improving the environment by reducing pollution, removing the consequences of pollution an increasing energy efficiency.

3) Increased quality of life and improved social cohesion in the region, through continuous investment in human resources.

4) Local economic development in the Pelagonia Region.

\section{REFFERENCES}

[1] Belak, Janko, et al. (1993): Podjetništvo, politika podjetja in menagement, Založba Obzorja, Maribor.

[2] Burns, P. (2001): Enterprise and Small Business, Palgrave Macmillan, London.

[3] Bygrave, D. W., Zacharakis A.: The portable MBA in Entrepreneurship, fourth edition, John Wiley\&Son. Inc: Hoboken, New Jersey.

[4] ИСПИ (1998): Сйрайетија, йолийика и уйравување со

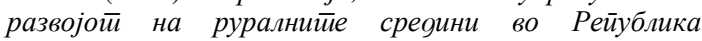
Макеgонија“, Трибина македонска, Скопје.

[5] Kostadinov, T., Cilev, G., Nikolova N. (2008): Small and Medium-Sized Enterprises in the Field of Agriculture in the Republic of Macedonia between Competitiveness Based Strategies and the Blue Ocean Strategy, Proceedings. International Conference for Entrepreneurship Innovation and Regional Development, Skopje-Ohrid. )

[6] Т. Костадинов (2011): Влијаниет̄о на иреиийрием-

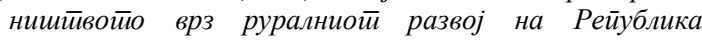
Макеgонија, докторска дисертација, Економски институт, Скопје

[7] Pavić, Ž. (2008): Poduzetništvo mladih i nova ekonomija, Ekonomski vjesnik, No. 1-2, Zagreb.

[8] Carter, Sara Jones-Evans Dylan (2000): Enterprise and Small Business, Prentice Hall, London.

[9] Siropolis N. C. (1995): Menadžment malog poduzeća, 4 izdanje, MATE, Hrvatska Obrtnička komora, Zagreb. 